\title{
Impact of Hands-on Science through School Gardening in Louisiana Public Elementary Schools
}

\author{
Leanna L. Smith ${ }^{1}$ and Carl E. Motsenbocker ${ }^{2}$
}

\begin{abstract}
AdDitionAl INDEX WORDs. science achievement, science education, service-learning, school gardens

SuMMARY. The first four chapters of a hands-on gardening curriculum (Junior Master Gardener Handbook Level One) were introduced into three East Baton Rouge Parish (Louisiana) elementary schools in the fall semester of 2002 as an informal education program conducted by East Baton Rouge Parish Master Gardener volunteers and Louisiana State University students. The curriculum took place once per week for 2 hours during regular school hours. Science achievement tests, developed at Texas A\&M University specifically for the Junior Master Gardener program, were given before and after the students participated in the gardening activities to determine whether or not the activities helped improve achievement scores. Science achievement was significantly different $(P \leq 0.0167)$ between the experimental classes' pretest and posttest scores, while no significant difference was found between the pretest and posttest scores of the control classes. No significant difference was found between the experimental and control classes due to treatment. Several variables may have affected the outcome of the study, but the results show once weekly use of gardening activities and hands-on classroom activities help improve science achievement test scores.
\end{abstract}

G ardens have been utilized in schools in the United States since the late 1890s and early 1900s (Bachert, 1976). Research to quantify the effects of school gardens, however, is relatively new. Many articles have been written by educators relating the qualitative effects of school gardens on students (Bradley, 1995; Canaris, 1995; Hanscom and Leipzig, 1994; Marturano, 1995; Meyer et al., 2001; Monk, 1995; Neer, 1990; Nelson, 1988; Sarver, 1985; Thompson and Marcoux, 1996), but few studies have been conducted. To quantify their benefits, studies have been conducted to examine the wide range of effects such as a garden's effect on environmental attitude (Skelly and Zajicek, 1998), on nutrition (Lineberger and Zajicek, 2000 ), on social interaction and interpersonal skills (Waliczek et al., 2001), and science achievement (Klemmer, 2002). More studies such as these are needed to further evaluate the benefit of having a garden in schools.

Studies have been conducted to assess the factors which influence

Dept. of Horticulture, Louisiana State University AgCenter, 137 Julian C. Miller Hall, Baton Rouge, LA 70803 .

${ }^{1}$ Graduate Student.

${ }^{2}$ Professor. teacher use of gardens (DeMarco et al., 1999; Dobbs et al., 1998; Mirka, 1970). One factor is having the available space, but gardens do not have to be in large areas (Braun et al., 1989). Gardening can be brought inside by the use of Grow Labs (National Gardening Assn., Burlington, Vt.) or similar structures (Gwynn, 1988; Hanscom and Leipzig, 1994) that facilitate gardening activities in northern climates and areas with little outdoor green space. The purpose of a school garden is not to have an elaborate landscape, but to create a "living laboratory" for student observation of science concepts in the real world and experimentation in an unpredictable environment. In addition, students need to feel that what they are learning in the classroom has a function in their everyday life (Fusco, 2001; Nelson, 1988; Reinsmith, 1993).

Educators have reported that school gardens and science can be used to teach across the curriculum (Mechling and Kepler, 1991) which can be particularly helpful in selfcontained classrooms. Concepts and skills from virtually every subject can be learned through a garden (Braun et al., 1989). Gardens also provide a link between concepts learned in the classroom and real life applications
(Mohrmann, 1999). In California, legislators acknowledged the effectiveness of school gardens to teach nutrition and provide other benefits to students by passing legislation that provides for the promotion, implementation, and support of instructional gardens by school districts and county education offices provided funding becomes available from areas other than state funds (State of California, 2000). Organization and support of school gardening will hopefully be realized sometime in the future in many states; until then, more research into the benefits and effects of gardening is needed.

\section{Materials and methods}

An experiment was conducted to quantify the effects of a school garden and garden curriculum on the science achievement of fifth grade students in three inner-city East Baton Rouge Parish, La., elementary schools (Park, Bernard Terrace, University Terrace) from Aug. to Dec. 2002.

Several factors played a part in the final selection process of the three schools for the study, such as having enough green space for a garden area, cooperative principal and teacher, two self-contained, mainstream, fifth grade classrooms and a location close to downtown Baton Rouge. All three of the schools were very similar in their demographics. According to the 200001 statistics (Ersys Development Team, 2003), the populations of the schools ranged from 377 to 507 students. Each school was primarily African-American in racial make-up with a 15:1 or less pupil to teacher ratio.

At two of the three schools, both the experimental and control classes were primarily African-American. The third school's experimental and control classes contained students from a wide range of ethnicities. This school is located in close proximity to the Louisiana State University campus (Baton Rouge) and had a very diverse ethnic make-up due to a large refugee population and foreign graduate student population in the neighborhood. The class sizes ranged from 17 to 33 in both the experimental and control classes.

Curriculum. The Junior Master Gardener (JMG) Handbook Level 1 (Whittlesey et al., 1999) for grades 3 through 5 developed at Texas A\&M University was the hands-on gardening curriculum chosen for classroom 
integration. This program targeted the age group selected and was chosen due to its thoroughness and interesting activities. Only the first four chapters out of the eight total in the teacher/leader guide were used in this study as they were introduced in the informal education program. Select activities were chosen and implemented in a 14-week period. In addition to the hands-on science activities, garden activities were performed. These were not specified in the JMG program, but were supplemental to the formal activities.

This program was implemented as an informal education program. Volunteers were used to assist in teaching and were from a Louisiana State University horticultural science service-learning class. In addition, Louisiana Master Gardeners helped teach the curriculum. Volunteers from these two groups went into the schools for $2 \mathrm{~h}$ each week to lead the lessons and work in the gardens. Each week, approximately the first $1.5 \mathrm{~h}$ was used for the JMG program activities and the last $0.5 \mathrm{~h}$ was used for garden time. During the semester approximately $4 \mathrm{~h}$ were spent on the 10 activities chosen from the first chapter (Plant Growth and Development), slightly less than $3 \mathrm{~h}$ on the six activities chosen from the second chapter (Soils and Water), approximately $3 \mathrm{~h}$ on the seven activities chosen from the third chapter (Ecology and Environmental Horticulture), and approximately 2.5 $\mathrm{h}$ on the five activities chosen from the fourth chapter (Insects and Diseases). Most of the volunteers had never taught children before and had to be guided in leading the lessons at the start of the program. The schools varied in the total number of volunteers assigned due to differing class size. The presence of the volunteers, however, allowed the classes to be divided into small groups of four to six per group. The presence of the adult volunteers for supervision also allowed for greater management of the fifth grade students while in the garden.

The gardening space for each school was standardized with each school having three $4 \times 10$ - $\mathrm{ft}$ garden beds $(1.2 \times 3.0 \mathrm{~m})$ for the students as their outdoor classroom area. Students planted herbs such as mint (Mentha xpiperita), rosemary (Rosmarinus officinalis), parsley (Petroselinum crispum), and basil (Ocimum bascilicum); and cool-season vegetables such as broccoli (Brassica oleracea var. italica), radish (Raphanussativus), lettuce (Lactucaspp.), carrot (Daucuscarota), and potato (Solanum tuberosum). The classrooms bought watering cans and were given fish emulsion for fertilizer. It was the responsibility of the teacher and students to make sure the garden was properly watered and fertilized.

InSTRUMENTATION. Testing for the study consisted of a science achievement pretest at the beginning of the semester on the first day of activities and then a posttest at the end of the fall program. A 40-question test developed at Texas A\&M University, based on the Junior Master Gardener program, was used for the evaluation (Klemmer, 2002). The testing instrument showed reliability (Cronsbach's alpha $=0.403$ ) and validity for the Texas Essential Knowledge and Skills as reported by Klemmer. The test was divided into four, 10-question sections covering the first four chapters of the program. Students were given as much time as needed to finish the test. For each experimental class there was a corresponding control class within the school and grade. Pretesting for the control class did not take place until 8 weeks into the semester due to time conflicts and the inability to get permission forms returned promptly. Posttesting for the control class was conducted 1 week after the experimental classes.

The data obtained from the pretest and posttest scores of the 62 fifth grade students in the experimental classes and the 57 students in the control classes were analyzed using an analysis of variance (ANOVA) (SAS version 8 for Windows; SAS Institute, Cary, N.C.). The main effects [gender, treatment (TRT), pretest vs. post] and interactions $($ TRT $\times$ gender, gender $\times$ pretest vs. post, TRT $\times$ pretest vs. post, TRT $\times$ gender $\times$ pretest vs. post) were subjected to ANOVA. Scores for the 40 -point test were multiplied by 2.5 to transform the scores to a 100-point scale. Pretest and posttest scores were analyzed for differences in both the experimental and control classes to determine if a garden program treatment influenced test scores. A paired $t$ test was performed on the science achievement scores in the experimental classes to compare their pretest scores to their posttest scores and determine if there was a significant difference in the means. The same paired $t$ test was performed on the scores from the control classes. Paired $t$ tests were also performed to determine differences in chapter scores.

\section{Results and discussion}

The effect of gender $(P \geq 0.5353)$ and treatment $(P \geq 0.0832)$ on science achievement test scores were nonsignificant (Table 1). The variable pretest vs. posttest is a comparison of the pretest and the posttest scores of each student regardless of treatment to determine if there was a difference in the two scores. Students science test scores were significantly higher $(P \geq 0.0171)$ in post-compared to the pretest results. The interaction between treatment, gender, and the pretest vs. posttest variable was also significant $(P<0.0219)$. The significant interaction resulted from the control group females remaining level in their pretest to posttest scores (data not presented). No other ANOVA interactions were significant.

There was a significant increase $(P$ $\geq 0.0167$ ) in mean test scores for the experimental group (3.40) when the

Table 1. Analysis of variance results (Type III) of fixed effects showing main effects and interactions for science achievement test results after inner-city fifth grade public school (Park, University Terrace, and Bernard Terrace elementary schools, Baton Rouge, La.) children participation in an in-school gardening program. ${ }^{\mathrm{z}}$

\begin{tabular}{lcccc}
\hline Effect & df & Den $^{\mathrm{y}}$ df & F & $P>$ F \\
\hline Gender $(\mathrm{G})$ & 1 & 113 & 0.39 & 0.5353 \\
Treatment $(\mathrm{T})$ & 1 & 113 & 3.06 & 0.0832 \\
$\mathrm{~T} \times \mathrm{G}$ & 1 & 113 & 0.07 & 0.7924 \\
Pretest vs. post & 1 & 115 & 5.86 & $0.0171^{*}$ \\
$\mathrm{G} \times$ pretest vs. post & 1 & 115 & 1.46 & 0.2291 \\
$\mathrm{~T} \times$ pretest vs. post & 1 & 115 & 0.20 & 0.6594 \\
$\mathrm{~T} \times \mathrm{G} \times$ pretest vs. post & 1 & 115 & 5.40 & $0.0219^{*}$ \\
\hline
\end{tabular}

${ }^{2}$ Chapters 1-4, Junior Master Gardener; participation once per week ( $2 \mathrm{~h}$ ) for 15 weeks. ven $=$ denominator

"Significant at $P \leq 0.05$ 
test scores where analyzed separately with paired $t$ tests (Table 2 ). In contrast, the difference in control group pretest and posttest scores (1.18) was not significant (Table 2 ). Gender was not a significant variable in pretest and posttest scores paired $t$ test analysis.

Scores on the blocks of questions derived from material of each chapter were analyzed separately. Analysis of chapter one (Plant Growth and Development) test scores using a paired $t$ test showed a significant difference $(P \geq 0.0001)$ between the pretest and posttest means of the experimental classes while the control test scores were not different (Table 3 ). There were no statistical differences for either the experimental or control classes in pretest and posttest subscores for the other three chapters. This results can be explained due to the time spent and the number of activities performed from chapter one compared to the other chapters.

Only the experimental class at University Terrace Elementary showed significant differences $(P \leq 0.016)$ in science achievement (40 questions) pretest and posttest means (Table 4). The experimental classes at Park Elementary and University Terrace Elementary had significant positive differences in the pretest and posttest means for chapter one and four, respectively (Table 5 ). The experimental class at Park Elementary, however, had a significant negative change in chapter four pretest and posttest scores. As an addition to the gardening curriculum, an entomologist participated in two of the three schools during the time chapter 4 (Insects and Diseases) activities were being covered. The entomologist brought in live specimens for the students to see and touch and also presented an entertaining lecture. The negative results at Park Elementary could be partially explained as this school was the site with decreased time on this particular chapter due to class scheduling conflicts with required field trips. There were no differences in subscores for chapter two (Soils and Water), or chapter three (Ecology and Environmental Horticulture) results for the individual schools (data not presented).

Our results indicate that there were significant differences in pretest and posttest scores and that the differences were only in the experimental group scores. These results are similar

Table 2. Results and paired $t$ test analysis of science achievement pretest and posttest averages for the experimental and control groups of fifth grade inner-city public school (Park, University Terrace, and Bernard Terrace elementary schools, Baton Rouge, La.) children after completion of a gardening program. ${ }^{\mathrm{z}}$

\begin{tabular}{|c|c|c|c|c|c|c|}
\hline Group & $\mathbf{N}$ & $\begin{array}{l}\text { Pretest } \\
\text { mean }^{y}\end{array}$ & $\begin{array}{c}\text { Posttest } \\
\text { mean }^{\mathrm{y}}\end{array}$ & df & $t$ & $P^{\mathrm{x}}$ \\
\hline Experimental & 62 & 38.95 & 42.35 & 61 & 1.9996 & $0.0167^{*}$ \\
\hline Control & 57 & 36.45 & 37.63 & 56 & 2.0032 & 0.3924 \\
\hline
\end{tabular}

${ }^{\mathrm{z}}$ Chapters 1-4 of Junior Master Gardener program, participation 2 h once per week during school for 15 weeks. ycores ranged from $0-100$ points, 40 -question test.

${ }^{x}$ Two-tail paired $t$ test.

*Significant at $P \leq 0.05$

Table 3. Paired $t$ test analysis of science achievement pretest and posttest subscores by program chapter for the experimental and control groups after involvement in an in-school garden-based program. ${ }^{2}$

\begin{tabular}{|c|c|c|c|c|c|c|c|}
\hline Chapter $^{\mathrm{y}}$ & Treatment & $\mathbf{N}$ & $\begin{array}{l}\text { Pretest } \\
\text { mean }^{\mathrm{x}}\end{array}$ & $\begin{array}{c}\text { Posttest } \\
\text { mean }^{x}\end{array}$ & df & $t$ & $P^{\mathrm{N}}$ \\
\hline \multirow[t]{2}{*}{1} & Experimental & 62 & 4.23 & 5.19 & 61 & 1.9996 & $0.0001^{\mathrm{v}}$ \\
\hline & Control & 57 & 4.34 & 4.39 & 56 & 2.0032 & 0.9461 \\
\hline \multirow[t]{2}{*}{2} & Experimental & 62 & 3.69 & 3.90 & 61 & 1.9996 & 0.4087 \\
\hline & Control & 57 & 3.21 & 3.47 & 56 & 2.0032 & 0.3343 \\
\hline \multirow[t]{2}{*}{3} & Experimental & 62 & 4.10 & 4.18 & 61 & 1.9996 & 0.7287 \\
\hline & Control & 57 & 3.46 & 3.90 & 56 & 2.0032 & 0.2078 \\
\hline \multirow[t]{2}{*}{4} & Experimental & 62 & 3.56 & 3.66 & 61 & 1.9996 & 0.7240 \\
\hline & Control & 57 & 3.33 & 3.30 & 56 & 2.0032 & 0.8917 \\
\hline
\end{tabular}

${ }^{2}$ Chapters 1-4, Junior Master Gardener program. Fifth grade inner-city public school students (Park, University Terrace, and Bernard Terrace elementary schools, Baton Rouge, La.) were the participants during school $2 \mathrm{~h}$ each week for 15 weeks.

Chapter 1 = Plant Growth and Development; 2 = Soils and Water; 3 = Ecology and Environmental Horticulture; 4 = Insects and Diseases.

${ }^{\mathrm{x}} \mathrm{S}$ cores ranged from $0-10$ points, 10 -question science achievement test.

wwo-tailed paired $t$ test.

'Significant at $P \leq 0.001$

Table 4. Results and paired $t$ test analysis of pretest and posttest 40 question science achievement test results for both the experimental and control fifth grade classes in each inner-city public school (Park, University Terrace, and Bernard Terrace elementary schools, Baton Rouge, La.) after participation in an in-school gardening program. ${ }^{\mathrm{z}}$

\begin{tabular}{lllccccc}
\hline $\begin{array}{l}\text { Elementary } \\
\text { school }^{\mathrm{y}}\end{array}$ & Treatment & $\mathbf{N}$ & $\begin{array}{c}\text { Pretest } \\
\text { mean }^{\mathrm{x}}\end{array}$ & $\begin{array}{c}\text { Posttest } \\
\text { mean }^{\mathrm{x}}\end{array}$ & df & $t$ & $P^{\mathrm{v}}$ \\
\hline Bernard & Experimental & 21 & 40.73 & 44.75 & 20 & 2.0859 & 0.1140 \\
$\quad$ Terrace & Control & 18 & 44.58 & 47.78 & 17 & 2.1098 & 0.0738 \\
Park & Experimental & 27 & 37.50 & 39.18 & 26 & 2.0555 & 0.4743 \\
& Control & 25 & 35.00 & 34.10 & 24 & 2.0639 & 0.7366 \\
University & Experimental & 14 & 39.10 & 44.83 & 13 & 2.1604 & $0.0162^{*}$ \\
Terrace & Control & 14 & 28.58 & 30.90 & 13 & 2.1604 & 0.2790 \\
\hline
\end{tabular}

${ }^{2}$ Chapters $1-4$ of Junior Master Gardener program.

'Scores ranged from $0-100,40$-question test.

${ }^{x}$ Two-tailed paired $t$ test.

*Significant at $P \leq 0.05$.

to a study conducted in Texas with a larger student population consisting of third through fifth grade students (Klemmer 2002). Klemmer reported higher science achievement experimental posttest group test scores compared to the control group and that most of the difference occurred in fifth grade student test scores. In addition, Klemmer also reported no effect of gender in the experimental group while within gender there was significant increases in treatment group males compared to control in all three grades and in females in the fifth grade. Our study showed a trend of increases between pretest and posttest scores in experimental and control group males and in experimental group females, within gender was nonsignificant. 
Table 5. Paired $t$ test analysis of Junior Master Gardener program chapter one (Plant Growth and Development) and chapter four (Insects and Diseases) subscores of individual inner-city public elementary schools (Baton Rouge, La.) for both the experimental and control fifth grade classes before and after completion of an in-school gardening program.

\begin{tabular}{cclcccccc}
\hline School & Chapter & Trt $^{\mathrm{z}}$ & $\mathbf{N}$ & $\begin{array}{c}\text { Pretest } \\
\text { mean }^{\mathrm{y}}\end{array}$ & $\begin{array}{c}\text { Posttest } \\
\text { mean }\end{array}$ & df & $t$ & $\boldsymbol{P}^{\mathbf{x}}$ \\
\hline Bernard & 1 & EXP & 21 & 4.05 & 4.90 & 20 & 2.0859 & 0.0644 \\
Terrace & 1 & CON & 18 & 5.11 & 5.00 & 17 & 2.1098 & 0.7769 \\
& 4 & EXP & 21 & 4.24 & 4.76 & 20 & -1.4712 & 0.1568 \\
& 4 & CON & 18 & 4.37 & 4.42 & 17 & -0.1095 & 0.9140 \\
Park & 1 & EXP & 27 & 4.11 & 5.26 & 26 & 2.0555 & $0.0034^{* *}$ \\
& 1 & CON & 25 & 4.36 & 4.12 & 24 & 2.0639 & 0.6316 \\
& 4 & EXP & 27 & 3.33 & 2.41 & 26 & 2.0894 & $0.0466^{*}$ \\
& 4 & CON & 25 & 3.20 & 2.80 & 24 & 0.9341 & 0.3595 \\
University & 1 & EXP & 14 & 4.71 & 5.5 & 13 & 2.1604 & 0.1107 \\
Terrace & 1 & CON & 14 & 3.50 & 3.93 & 13 & 2.1604 & 0.2722 \\
& 4 & EXP & 14 & 3.00 & 4.43 & 13 & -3.3333 & $0.0054^{* *}$ \\
& 4 & CON & 14 & 2.43 & 2.50 & 13 & -0.1324 & 0.8967 \\
\hline
\end{tabular}

${ }^{\mathrm{z}} \mathrm{Trt}=$ treatment $; \mathrm{EXP}=$ experimental $; \mathrm{CON}=$ control.

y cores ranged from $0-10$ points, 10 questions per chapter.

xTwo-tailed paired $t$ test.

${ }^{* *}$ Significant at $P \leq 0.05$ and 0.01 , respectively.

In the current study the pretest and posttest experimental group scores showed a significant difference in paired $t$ tests while the ANOVA results showed no significant difference in test scores due to treatment. One factor that could have influenced the ANOVA results is the relatively low sample size used in the study. A larger sample population could have increased the test sensitivity. Other variables that possibly influenced the test results were the teaching experience of the volunteers and the level of teacher participation and follow-up during the week. In all but five out of 15 cases, the volunteers who went into the schools to work with the students had no formal training in education and they were primarily young and inexperienced undergraduate students. It is possible that the elementary school students, even though engaged in hands-on activities, did not receive the full benefit due to lack of proper teaching techniques and the inability of the volunteers to explain concepts at the fifth grade students' level.

Another variable, teacher participation, could also have played a role in the posttest outcomes. In this study, there was very little, if any, continuity between the gardening activities and the normal curriculum activities. Only one of the three teachers reported to have used concepts introduced through the JMG curriculum activities into the classroom during the remainder of the week. The teachers used the garden to different degrees, but the overall lack of continuity between the garden and the everyday classroom was most likely the greatest disadvantage to this study. Butts and Hofman (1993) expressed the need for hands-on activities to be followed with discussion and explanation of what has been experienced. Another factor would be the lack of incentive for the students to answer to the best of their ability on the achievement test. The students knew that the test would have no effect on their science grade and was purely for our research purposes.

\section{Conclusions}

Our study focused on a predominantly African-American student population in low-income, inner-city public schools, with some of the students being from disadvantaged backgrounds. These are the students who truly need educators to find new ways of engaging their students in science learning activities. This study shows that even with instructors who had little background in teaching methods and a once per week gardening session for students, some improvement in science achievement test scores can be attained. Positive results have been seen in other studies and accounts of gardens; however, more research needs to be conducted in this area before researchers can definitively say that gardens increase science achievement or achievement scores.

\section{Literature cited}

Bachert, R.E. 1976. History and analysis of the school garden movement in America, 1890-1910. PhD Diss., Indiana Univ., Bloomington.

Bradley, L.K. 1995. Tierra buena: The creation of an urban wildlife habitat in an elementary school in the inner-city. Children's Environ. 12(2):245-249.

Braun, J.A. Jr., M. Kotar, and J. Irick. 1989. Cultivating an integrated curriculum the school garden. Social Studies Young Learner. January/February:19-22.

Butts, D.P. and H. Hofman. 1993. Hands-on, brains-on. Sci. Children 30(5):15-16.

Canaris, I. 1995. Growing foods for growing minds: Integrating gardening and nutrition education into the total curriculum. Children's Environ. 12(2):264-270.

DeMarco, L., D. Relf, and A. McDaniel. 1999. Integrating gardening into the elementary school curriculum. HortTechnology 9(2):276-281.

Dobbs, K., D. Relf, and A. McDaniel. 1998. Survey on the needs of elementary education teachers to enhance the use of horticulture or gardening in the classroom. HortTechnology 8(3):370-373.

Ersys Development Team. 2003. Baton Rouge, LA school district statistics. 22 Apr. 2003. <www.ersys.com/ usa $/ 22 / 2205000 /$ sch_elem.htm>.

Fusco, D. 2001. Creating relevant science through urban planning and gardening. J. Res. Sci. Teaching 38(8):860-877.

Gwynn, M.L. 1988. A growing phenomenon. Sci. Children 25(7):25-26.

Hanscom, J.T. and F. Leipzig. 1994. The panther patch: A far north K to 6 gardening project. Green Teacher 38:10-13.

Klemmer, C.D. 2002. Growing minds: The effect of school gardening programs on the science achievement of elementary students. PhD Diss., Texas A\&M Univ., College Station.

Lineberger, S.E. and J.M. Zajicek. 2000. School gardens: Can a hands-on teaching tool affect students' attitudes and behaviors regarding fruit and vegetables? HortTechnology 10(3):593-597.

Marturano, A. 1995. Horticulture and human culture. Sci. Children 32(5):2630 .

Mechling, K.R. and L. E. Kepler. 1991. Start with science. Instructor 100(7):3538. 
Meyer, M.H., N.N. Hegland, and P. Fairbourne. 2001. Junior Master Gardener programs in Minnesota. HortTechnology $11(4): 665-667$.

Mirka, G.D. 1970. Factors which influence elementary teacher's use of the out-ofdoors. Master's Thesis, Ohio State Univ., Columbus.

Mohrmann, P. 1999. Planting the seeds of science: The school garden-A perfect laboratory for teaching science. Instructor 108(16):25-29.

Monk, S.K. 1995. Integrated curriculum in a tiny Texas garden. Dimensions Early Childhood 23(4):8-9.

Neer, K. 1990. A children's garden. Herbarist 56:69-76.

Nelson, C.J. 1988. Harvesting a curriculum. Sci. Children 25(7):22-24.

Reinsmith, W.A. 1993. Ten fundamental truths about learning. Natl. Teaching Learning Forum 2(4):7-8.

Sarver, M.D. 1985. Agritherapy: Plants as learning partners. Academic Therapy 20(4):389-396.

Skelly, S.M. and J.M. Zajicek. 1998. The effect of an interdisciplinary garden program on the environmental attitudes of elementary school children. HortTechnology 8(4):579-583.

State of California. 2000. California Education Code Section 51795-51798. 2 Apr. 2003. <http://www.leginfo.ca.gov/cgibin/displaycode? section $=$ edc $\&$ group $=51$ 001-52000\&file $=51795-51798>$.

Thompson, S. and M. Marcoux. 1996. Colonial science: Studying the colonial uses of herbs helps children link the past with the present. Sci. Children 33(5):12-15, 35.

Waliczek, T.M., J.C. Bradley, and J.M. Zajicek. 2001. The effect of school gardens on children's interpersonal relationships and attitudes toward school. HortTechnology $11(3): 466-468$.

Whittlesey, L., R. Seagraves, D. Welsh, and G. Hall. 1999. Junior Master Gardener teacher/leaders guide. Level 1. Texas A\&M Univ. Agr. Ext. Serv., College Station. 